Available online at website :

http:/ / e-journal.adpgmiindonesia.com/index.php/jmie

JMIE: Journal of Madrasah Ibtidaiyah Education, 5(2), 2021, 265-276

\title{
PENGARUH METODE BERNYANYI TERHADAP HASIL BELAJAR MATEMATIKA (PERKALIAN) PESERTA DIDIK MADRASAH IBTIDAIYAH
}

\author{
Nafia Wafiqni' ${ }^{1)}$, Ferdinni Haryanti ${ }^{2)}$ \\ Universitas Islam Negeri (UIN) Syarif Hidayatullah Jakarta ${ }^{1), 2)}$ \\ Email:nafia.wafiqni@uinjkt.ac.id ${ }^{1}$,ferdinni.haryanti@gmail.com²)
}

Submit: 22 Januari 2021, Revisi: 18 Agustus 2021, Approve: 8 November 2021

\begin{abstract}
The basis for this review is that at MI Al-Mursyidiyyah, especially in class III A, they have not used singing techniques. Then at that time the side effect of learning science in class III MI Al-Mursyidiyyah, there were $1 \%$ who had bad math scores. The reason for this review is to see whether there is an effect of the method on the mathematics learning outcomes of grade III A students. This test is directed at MI Al-Mursyidiyyah Pamulang, South Tangerang in September - November 2020. An example of the analysis class is class III A, which consists of 34 students obtained by Purposive Sampling. The method used is Pre-Experimental with One Group Pretest-Posttest Design (single meeting plan with pretest and posttest). The instrument used in this study was a cognitive test in the form of multiple choice. The data analysis technique used in this research is the n-gain test using a predetermined formula, the normality test using Shapiro Wilk, the homogeneity test using ANOVA (Anlysis of variance), the paired thypothesis test (Two Paired Samples Test). Based on the results of the t-test on the pretest and posttest of the experimental class with the results of the t-count value of 9.858 $>$ t-table 2.034 or $\mathrm{H} 0$ is rejected and $\mathrm{H} 1$ is accepted. So that it can be said that there is an effect of utilization on the mathematics learning outcomes of students of class III A MI AlMursyidiyyah Pamulang, South Tangerang.
\end{abstract}

Keywords: singing method, mathematics learning outcomes, multiplication.

Pengutipan: Nafia Wafiqni \& Ferdinni Haryanti. (2021). Pengaruh Metode Bernyanyi Terhadap Hasil Belajar Matematika (Perkalian) Peserta Didik Madrasah Ibtidaiyah. JMIE: Journal of Madrasah Ibtidaiyah Education, 5(2), 2021, 265-276. jmie.v5i2.298.

Permalink/DOI: http://dx.doi.org/10.32934/jmie.v5i2.298 
Nafia Wafiqni \& Ferdinni Haryanti

\section{PENDAHULUAN}

Hasil belajar sangat penting, baik untuk guru, wali murid dan peserta didik. Hasil belajar yaitu hasil peserta didik setelah kegiatan belajar berlangsung, meliputi kognitif, afektif, dan psikomotorik yang dapat dinyatakan dengan angka ataupun kalimat yang dapat mempresentasikan kualitas peserta didik pada proses tertentu. (Wahyuningsih, 2020) Hasil dalam pembelajaran memiliki manfaat khususnya kepada peserta didik yaitu, 1) Dapat menolong peserta didik memilih rencana kedepannya yang sesuai, 2) Jika terdefinisi dengan baik, dapat meminimalisir risiko terbuangnya waktu, 3) Dapat meminimalisir stress pada peserta didik, 4) Dapat menyampaikan rencana nyata kepada peserta didik tentang pembelajaran/sains yang akan mereka pelajari atau capai menjelang akhir kelas sebelum dimulainya kelas.. (Mahajan \& Singh, 2017)

Di sekolah, hasil belajar dapat diketahui guru dengan melakukan evaluasi kepada peserta didik. Melalui evaluasi yang dilaksanakan, akan didapat hasil akhir dalam pembelajaran yang dapat dilihat dalam aspek kognitif, aspek nilai atau sikap, dan aspek keterampilan. Evaluasi belajar adalah kegiatan yang dilakukan setiap akhir pembelajaran. Evaluasi hasil belajar dapat dikatakan baik jika peserta didik dapat melampaui KKM. KKM yaitu tolak ukur pada pembelajaran yang paling rendah untuk mengetahui ketuntasan peserta didik. Penetapan KKM dilakukan di awal tahun pembelajaran melalui musyawarah yang dilakukan oleh para guru. (Yendarman, 2016) Dengan KKM ini, peserta didik yang memiliki evaluasi melebihi KKM, mereka dapat mempelajari kompetensi selanjutnya. Tetapi, jika peserta didik memiliki evaluasi dibawah KKM, maka perlu pendalaman atau perbaikan melalui remidi. Maka dari itu, KKM sangat penting dalam menentukan kompetensi selanjutnya yang di pelajari oleh peserta didik. (Mardapi, Hadi, \& Retnawati, 2015). KKM pada mata pelajaran matematika di MI Al-Mursyidiyyah adalah 70.

Matematika adalah ilmu yang mengatur dengan penyelidikan struktur atau struktur teoritis dan hubungan di antara mereka.. (Yusmanto, 2018) Matematika adalah ilmu yang diperoleh dengan cara berpikir, membicarakan hal-hal yang dipelajari dalam ilmu itu sendiri, mulai dari perluasan, deduksi, dll. (Trygu, 2020). Berdasarkan beberapa pengertian matematika diatas, matematika yaitu ilmu pengetahuan yang diperoleh dengan berpikir, ilmunya berhubungan dengan struktur-struktur yang abstrak dan membahas mulai dari operasi penjumlahan, pengurangan, dan lain sebagainya.

Matematika merupakan ilmu dasar pada setiap ilmu. Matematika sudah mulai diajarkan pada jenjang pendidikan taman kanak-kanak hingga jenjang perkuliahan. Pada kehidupan sehari-hari, matematika sering digunakan, seperti pada kegiatan jual-beli, menghitung barang, dan kegiatan lainnya. Pada pembelajaran matematika, peserta didik dituntut untuk dapat memahami konsep yang mereka pelajari karena setiap materi yang diajarkan pada matematika saling berkaitan. Perserta didik pun harus aktif dalam memecahkan permasalahan pada pembelajaran matematika. 
Pada penelitian ini, peneliti melaksanakan penelitian pada pembelajaran matematika dengan materi perkalian. Empat dari satu operasi dasar pada matematika yaitu perkalian (yang lainnya yaitu penjumlahan, pengurangan, dan pembagian). Perkalian dapat didefinisikan sebagai penjumlahan berulang. (Yulianto, 2015) Peserta didik sekolah dasar sangat diwajibkan untuk menghafal perkalian 1 hingga 10. Ini berharga sehingga pestra didi dapat mengatasi masalah yang berisi perkalian tanpa masalah.

Guru dan peserta didik merupakan yang terpenting pada sekolah. Guru merupakan seseorang yang lebih banyak bersama dengan peserta didik. Maka dari itu, guru dapat diibaratkan seperti ujung tombak yang selalu berada di depan untuk berhadapan langsung dengan peserta didik. Lalu, peserta didik dalam pendidikan merupakan sentral, yang artinya guru harus dapat membimbing mereka agar dapat mencapai tujuan secara optimal dan mencapai hasil belajar yang baik. Selain membimbing, guru pun harus dapat mengatasi permasalahan-permasalahan yang muncul pada saat pembelajaran, maupun permasalahan yang dihadapi peserta didik ketika pembelajaran berlangsung.

Beberapa permasalahan dapat kita temui pada setiap jenjang pendidikan, matematika merupakan salah satu permasalahan yang sering ditemui. Beberapa peserta didik sudah beranggapan bahwa matematika adalah pembelajaran sulit. Ini dikarenakan matematika yang selalu berkaitan dengan angka, menghafal rumus, dan hitung-menghitung. Faktor lainnya yaitu setiap materi pada matematika saling berkaitan, maka dari itu peserta didik di tuntut untuk menghafal materi atau rumus matematika. Kemudian, pada saat itu, satu lagi variabel yang menyebabkan rendahnya nilai matematika seperti yang ditunjukkan oleh Tuti Tuarsih, pemerhati pendidikan di Kabupaten Lebak adalah karena tidak adanya imajinasi instruktur dalam sistem pengajaran kepada peserta didiknya. Selain itu, penyampaian contoh matematika tidak menggunakan teknik yang menyenangkan. (Joewono, 2013)

Saat ini, pemerintah mengharuskan seluruh sekolah menjalani pembelajaran jarak jauh (online school. Penyebab seluruh sekolah menjalani pembelajaran jarak jauh yaitu dikarenakan keadaan yang sedang terjadi (covid-19) dari awal tahun hingga waktu yang tidak ditentukan. Sekolah dapat menggunakan media perantara seperti video dan aplikasi seperti Whatsapp, Youtube, Zoom, Google dalam pembelajaran jarak jauh. Walaupun begitu, dalam hasil wawancara yang dilakukan dengan wali kelas III A MI Al-Mursyidiyyah, guru mengalami kesulitan selama pembelajaran jarak jauh, khususnya pada mata pelajaran matematika yaitu: 1)Pemahaman peserta didik dari materi yang sudah kita sampaikan agak lama, dikarenakan kita tidak melakukan pembelajaran offline; 2) Keterbatasan ruang dan waktu. Karena kita tidak bisa bertemu langsung dan waktu belajar matematika menjadi lebih sedikit yang seharusnya tidak seperti itu; 3) Keterbatasan kuota (internet). Pada saat pembelajaran jarak jauh ini, baik peserta didik maupun guru harus mengirim video dan melakukan videocall. Itu semua memakan banyak kuota; 4)Tugas-tugas telah diberikan 
Nafia Wafiqni \& Ferdinni Haryanti

oleh guru. Tetapi, kita tidak tahu peserta didik paham atau tidak; 5) Terdapat 1\% yang memiliki nilai matematika tidak baik dan dikarenakan peserta didik tersebut tidak aktif.

Untuk mengatasi permasalahan dan kesulitan diatas, maka perlu adanya pendekatan atau metode pembelajaran. Banyak pendekatan dan metode yang dapat digunakan guru saat pembelajaran. Guru pun harus teliti dan kreatif dalam memilih metode pembelajaran yang ingin digunakan karena metode pembelajaran dapat memengaruhi hasil belajar. Salah satu teknik yang dapat dimanfaatkan dalam pembelajaran matematika adalah metode bernyanyi. (Muhammad, 2012) Menjelaskan metode bernyanyi dapat diartikan sebagai metode pembelajaran yang memanfaatkan soneta yang dinyanyikan.

Metode bernyanyi dapat digunakan di berbagai tingkat pendidikan. Ini dikarenakan metode bernyanyi mudah digunakan dan memiliki banyak manfaat. Manfaat metode bernyanyi seperti: 1) membuat mata pelajaran yang tidak menarik menjadi lebih menarik, 2) peserta didik lebih mudah menyerap pembelajaran karena lirik dan lagu yang digunakan dapat disesuaikan dengan pembelajaran, 3) dapat membantu mempertajam daya ingat peserta didik, 4) kosakata peserta didik dapat bertambah, 5) dapat meningkatkan percaya diri peserta didik.

Bernyanyi tidak pernah lepas dari musik dan lirik lagu. Cara untuk menikmati musik salah satunya dengan bernyanyi. Musik adalah bentuk seni yang ideal untuk diintegrasikan dalam pengajaran matematika. Konsep musik ini terkait dengan konsep matematika proporsi dan hubungan numerik, bilangan bulat, logaritma dan operasi aritmatika. (An, Capraro, \& Tillman, 2013) Peneliti menggunakan musik sebagai alat pendukung dalam metode bernyanyi. Jika hanya bernyanyi tanpa lagu, peserta didik akan merasa bosan dan terlalu sepi karena hanya guru dan peserta didik yang bernyanyi. Musik yang digunakan harus sebanding dengan usia peserta didik. Dalam ulasan ini, analis menggunakan melodi anak-anak dan hanya menggunakan instrumen. Peneliti juga menggunakan lirik dalam lagu karena lirik sangatlah penting pada sebuah lagu. Lirik lagu anak-anak di ubah kedalam perkalian 1-10.

Penelitian yang dilakukan Vera Triatnasari pada tahun 2017, dengan judul "Penggunaan Metode Bernyanyi Dalam Meningkatkan Hasil Belajar Siswa Kelas III B MIN 11 Bandar Lampung". Pada penelitian yang dilakukan Vera, hasil penelitian tersebut yaitu dari 24 peserta didik, yang tuntas dalam mata pelajaran kelas III B hanya 8 orang peserta didik dengan persentase sebesar 33,4\% dan yang tidak tuntas 16 dengan persentase sebesar 66,7\%. Kemudian pada siklus utama tersebut, 14 siswa tuntas dengan taraf 58,3\% dan 10 siswa tidak tuntas dengan taraf 41,7\%. Pada siklus II siswa yang menyelesaikan 21 siswa dengan taraf 87,5\% dan siswa yang tidak menyelesaikan 3 siswa dengan taraf 12,5\%. Peningkatan hasil belajar peserta didik dalam penggunaan metode bernyanyi sudah terlihat pada siklus II. Perbedaan pada penelitian yang dilakukan Vera dengan yang dilakukan peneliti adalah tempat pelaksanaan penelitian dan metode penelitian yang dilakukan. 
Lalu, penelitian yang dilakukan oleh Nila Prasiwi, dari IAIN Purwokerto, tahun 2020 dengan judul "Pengaruh Metode Bernyanyi Terhadap Peningkatan Hasil Belajar Siswa Pada Mata Pelajaran IPS Kelas IV MI Negeri 2 Banyumas". Hasil penelitian tersebut yaitu pada kelas yang menggunakan metode bernyanyi mendapatkan rata-rata skor 0,71 n-gain. Sedangkan kelas yang menggunakan metode konvesional mendapatkan rata-rata skor 0,41 n-gain. Ada perbedaan penting antara peserta didik yang menggunakan metode menyanyi dan metode biasa. Dari penelitian yang telah dilakukan oleh Nila Prasiwi, ada perbedaan pada penelitian yang dilakukan oleh peneliti. Perbedaannya terdapat dari mata pelajaran yang diteliti dan metode penelitian yang digunakan.

Sebagai upaya menjawab segala kesulitan dan permasalahan yang telah diuraikan, maka peniliti tertarik untuk melakukan penelitian yang berjudul "Pengaruh Metode Bernyanyi Terhadap Hasil Belajar Peserta Didik Kelas III A Pada Pembelajaran Matematika (Perkalian) di MI AlMursyidiyyah."

\section{METODE PENELITIAN}

Penelitian ini dilaksanakan di MI Al-Mursyidiyyah. Penelitian ini dilakukan pada tahun 2019/2020. Jenis penelitian yang digunakan adalah Pre-Eksperimental Design (desain praeksperimen). Pra-Eksperimental Design merupakan rencana eksplorasi yang tidak signifikan, dengan alasan terdapat faktor-faktor luar yang mempengaruhi perkembangan variabel terikat. Jadi konsekuensi eksplorasi dari variabel terikat tidak hanya dipengaruhi oleh variabel otonom. Ini bisa terjadi karena tidak ada variabel kontrol, dan contoh tidak diambil tanpa tujuan. (Sugiyono, 2015).

Metode penelitian yang digunakan adalah One Group Pretest-Posttest Design (desain kelompok tunggal dengan pretest dan posttest). One Group Pretest-Posttest Design adalah perencanaan yang menggunakan satu kelas saja, yaitu kelas tes tertentu dan melihat konsekuensi dari pretest dan posttest dari kelas tes tersebut. Pada penelitian ini, hasil posttest dan pretest yang akan dibandingkan pada kelas eksperimen yaitu kelas III A.

Populasi dalam penelitian ini adalah peserta didik kelas III MI Al-Mursyidiyyah dengan jumlah 89 pada tahun ajaran 2019/2020. Sampel yang digunakan adalah peserta didik III A MI AlMursyidiyyah. Sampel dipilih dengan purposive sampling yaitu teknik menentukan sampel dengan beberapa pertimbangan.

Sampel dipilih dengan cara purposive sampling, tepatnya strategi penentuan sampel dengan beberapa perenungan. Perenungan peneliti memilih kelas III A adalah kelas III A memiliki jumlah peserta didik yang lebih sedikit yaitu 34 dari kelas III B yang berjumlah 35 dan III C yang berjumlah 35. Menurut (Tarigan, 2013) salah satu kekurangan pada metode bernyanyi adalah sulit bila digunakan pada kelas besar. Maka dari itu, kelas III A cocok untuk dijadikan objek penelitian. 
Nafia Wafiqni \& Ferdinni Haryanti

Peneliti menggunakan teknik pengumpulan data berupa tes dan non tes. Pada tes, peneliti menggunakan pre-test dan posttest. Pre-test dilaksanakan sebelum diberi treatment/perlakuan, lalu posttest dilaksanakan setelah diberi treatment/perlakuan. Peserta didik kelas III A akan diberikan soal pretest matematika. Setelah diberikan pretest maka selanjutnya peserta didik diberikan treatment berupa metode bernyanyi. Untuk mengetahui adakah pengaruh hasil belajar matematika peserta didik setelah diberikan treatment atau tidak, maka peneliti membagikan soal posttest kepada peserta didik kelas III A MI Al-Mursyidiyyah. Pada non tes terdapat wawancara. Wawancara dilakukan dengan wali kelas III A melalui perantara Whatsapp. Hasil wawancara digunakan untuk memperkuat penelitian ini.

Instrument penelitian yang digunakan peneliti adalah instrumen soal tes, dikarenakan peneliti ingin mengetahui hasil belajar matematika dengan materi perkalian peserta didik sebelum dan sesudah menggunakan metode bernyanyi. Cara-cara yang ditempuh dalam penataan instrumen tes adalah:

1. Membuat kisi-kisi soal berdasarkan K13 dan modul yang diberikan guru kelas III A mata pelajaran Matematika semester 1 materi perkalian. Saat pembuatan kisi-kisi, peneliti dibantu oleh wali kelas III A.

2. Membuat soal tes berdasarkan kisi-kisi beserta kunci jawaban.

3. Berdiskusi dengan dosen pembimbing dan wali kelas III A mengenai soal-soal.

4. Melakukan uji instrumen di kelas III A MI Al-Mursyidiyyah.

5. Mengkaji perolehan uji instrumen yang mencakup uji validitas butir soal, reliabilitas instrumen, dan tingkat kesukaran, lalu berdiskusi kembali dengan dosen pembimbing.

Pelaksanaan penelitian dilakukan pada peserta didik kelas III A MI Al-Mursyidiyyah. Pelaksanaan penelitian dilakukan secara online/daring mengingat kondisi sekarang yang tidak memungkinkan untuk melakukan pembelajaran secara offline, berikut proses penelitian yang dilakukan dengan cara online dan offline:

1. Penelitian dilaksanakan secara online dengan dibantu oleh wali kelas III A,

2. peneliti menjadi shadow teacher, dengan wali kelas III A yang mengajar peserta didik kelas III A dengan menggunakan Whatsapp sebagai perantara untuk memberikan tugas/videocall,

3. peneliti memberikan soal validasi mata pelajaran matematika materi perkalian kepada wali kelas III A secara langsung dengan datang ke sekolah. Lalu, wali kelas III A akan memberikan soal kepada wali murid secara langsung bersamaan dengan memberikan modul,

4. peneliti mengambil kembali soal validasi yang telah dijawab oleh peserta didik kelas III A ke MI Al-Mursyidiyyah,

5. peneliti memberikan soal pretest mata pelajaran matematika materi perkalian kepada wali kelas III A secara langsung dengan datang ke sekolah. Lalu, wali kelas III A akan memberikan soal kepada wali murid secara langsung bersamaan dengan memberikan modul, 
6. peneliti mengambil kembali soal pretest yang telah dijawab oleh peserta didik kelas III A ke MI Al-Mursyidiyyah,

7. peneliti mengirimkan link video perkalian bernyanyi melalui Whatsapp kepada wali kelas III A, 8) wali kelas III A mengirimkan link video perkalian bernyanyi ke grup Whatsapp wali murid kelas III A dengan tujuan untuk ditonton oleh peserta didik,

8. peneliti mengirimkan link Google Form soal posttest mata pelajaran matematika materi perkalian melalui Whatsapp kepada wali kelas III A,

9. wali kelas III A mengirimkan link Google Form soal posttest ke grup Whatsapp wali murid kelas III A dengan tujuan untuk dijawab oleh peserta didik.

Analisis data adalah teknik untuk mencari dan menggabungkan informasi terorganisir yang diperoleh dari pertemuan, dan lain-lain, dengan tujuan agar informasi tersebut terbuka secara efektif dan dapat diinformasikan kepada orang lain. (Wijaya, 2018) Analisis data dilakukan untuk mengetahui pengaruh metode bernyanyi terhadap hasil belajar matematika materi perkalian peserta didik kelas III A MI Al-Mursyidiyyah. Dalam penelitian ini, peneliti menggunakan teknik uji t berpasangan (Two Paired Samples Test) pada program IBM SPSS Statistics 20.

\section{HASIL DAN PEMBAHASAN}

Dalam pebelajaran, hasil belajar secara konsisten menjadi acuan untuk melihat peningkatan peserta didik selama pembelajaran. Kemajuan peserta didik dapat dilihat dari segi intelektual, penuh perasaan dan psikomotorik. Oleh karena itu, guru dan seluruh staf sekolah harus bekerjasama dalam mengembangkan hasil belajar peserta didik lebih lanjut. Peserta didik juga harus memiliki energi dan kegembiraan dalam belajar. Pendidik harus memiliki imajinasi dengan tujuan agar peserta didik selalu bersemangat dalam belajar. Guru dapat memanfaatkan teknik atau strategi yang berbeda selama pembelajaran. Pemanfaatan strategi pembelajaran dapat membuat guru mengetahui perilaku peserta didik dan peserta didik lebih efektif menyerap materi pembelajaran.

Ada banyak metode pembelajaran dan dapat digunakan dalam berbagai mata pelajaran. Bagaimanapun, instruktur harus berhati-hati dalam memilih strategi pembelajaran, karena mereka dapat mempengaruhi hasil belajar siswa. Salah satu teknik yang tidak sulit untuk digunakan adalah strategi menyanyi. Teknik menyanyi merupakan strategi yang digunakan dengan cara menyanyi dengan syair-syair melodi yang diubah menjadi bahan ajar yang diajarkan. Strategi bernyanyi dapat digunakan dalam berbagai mata pelajaran, salah satunya adalah IPA. Dalam aritmatika, strategi bernyanyi dapat digunakan untuk mempertahankan resep, dan langit adalah batasnya dari sana. Metode bernyanyi memiliki langkah-langkah dalam pelaksanaannya, yaitu:

1. Guru memberitahu materi yang sudah digabungkan dalam nyanyian melalui tanya jawab kepada peserta didik, 
Nafia Wafiqni \& Ferdinni Haryanti

2. guru menyanyikannya sebanyak dua atau tiga kali,

3. peserta didik bersama guru menyanyikan lagu bersama-sama, suara guru akan semakin pelan agar guru dapat mengetahui bahwa peserta didik sudah mulai hafal,

4. guru menanyakan kepada peserta didik kata-kata yang sulit mereka pahami dan guru menjelaskannya,

5. peserta didik bersama guru menyanyikan kembali lagunya dengan semangat

6. guru memberikan kesempatan kepada peserta didik yang ingin menyanyikan lagu di depan kelas,

7. guru selalu memberikan dorongan dan semangat kepada peserta didik selama bernyanyi bersama (Depdikbud, 1991)

Tetapi, dikarenakan keadaan saat ini menjadikan metode bernyanyi tidak dapat dilaksanakan seperti langkah-langkah diatas. Pada pembelajaran jarak jauh, metode bernyanyi dapat digunakan melalui perantara yaitu video yang dapat diunggah ke laman Youtube. Video bernyanyi perkalian 110 dibuat dengan background yang menarik. Berikut contoh gambaran pada video bernyanyi perkalian 1-10:

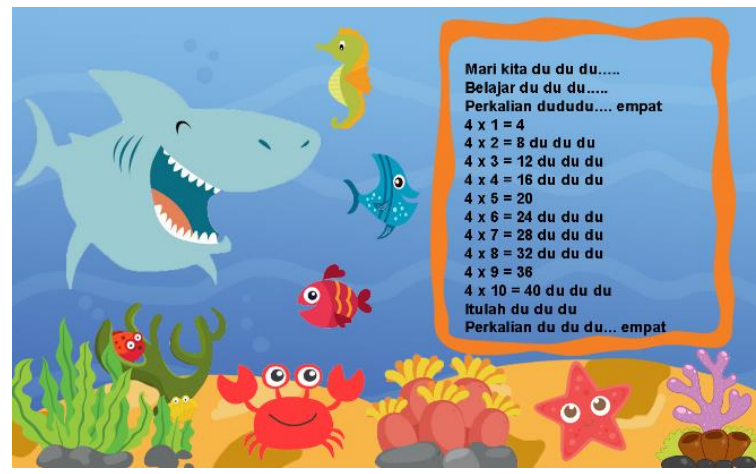

\section{Gambar 1 Desain video bernyanyi untuk perkalian 4}

Pada video bernyanyi perkalian 1-10, peneliti menyanyikan liriknya dengan iringan instrument lagu anak-anak. Lirik akan muncul satu per satu sesuai dengan nyanyian peneliti. Setelah selesai membuat, lalu diunggah ke laman Youtube dan linknya diberikan kepada wali kelas III A agar wali kelas III A dapat memberikannya ke orang tua peserta didik. Peserta didik dapat menonton video bernyanyi perkalian 1-10 berulang kali di Youtube agar dapat menghafal perkalian 1-10 dan mengerjakan soal perkalian dengan mudah.

Setelah peserta didik diberikan treatment berupa pelaksanaan pembelajaran matematika materi perkalian dengan metode bernyanyi di kelas eksperiman yaitu kelas III A, maka selanjutnya yaitu mengadakan posttest. Terdapat pengambilan keputusan dengan, jika nilai t hitung $>\mathrm{t}$ tabel, maka $\mathrm{H}_{0}$ ditolak dan $\mathrm{H}_{1}$ diterima. Jika nilai t hitung $<\mathrm{t}$ tabel, maka maka $\mathrm{H}_{0}$ diterima dan $\mathrm{H}_{1}$ ditolak. $\mathrm{T}$ tabel ditentukan berdasarkan nilai df (degree of freedom) dan nilai signifikansi $(\alpha / 2)$. Nilai df ditentukan dengan rumus n-1. $\mathrm{N}$ yaitu jumlah peserta didik pada kelas III A, maka 34-1 = 33 . 
Pada nilai signifikansi 0,05/2 sama dengan 0,025. T tabel pada df 33 dengan nilai signifikansi 0,025 adalah 2,03452. Untuk hasil t hitung di dapat melalui perhitungan dengan program IBM SPSS Statistics 20. Berikut tabel hasil uji statistik untuk t hitung:

Tabel 1. Hasil Uji T-Test Pretest dan Posttest Kelas Eksperimen

\begin{tabular}{ccccccc}
\hline Pair 1 & Mean & $\begin{array}{c}\text { Std. } \\
\text { Deviatiom }\end{array}$ & df & $\mathbf{t}_{\text {hitung }}$ & $\begin{array}{c}\text { Sig. (2- } \\
\text { tailed) }\end{array}$ & Kesimpulan \\
\hline $\begin{array}{l}\text { Pretest }- \\
\text { Posttest }\end{array}$ & -24.706 & 2.506 & 33 & -9.858 & .000 & $\mathrm{H}_{0}$ ditolak \\
\hline
\end{tabular}

Berdasarkan tabel diatas yang diambil dari hasil pada program IBM SPSS Statistics 20, di dapat nilai t hitung yaitu -9,858 dari pretest dan posttest. T hitung bernilai negatif dikarenakan nilai ratarata hasil belajar pretest lebih rendah dari nilai rata-rata hasil belajar posttest, maka t hitung negatif dapat bermakna positif atau menjadi 9,858.

Hasil yang didapat pada uji hipotesis data pretest dan posttest, nilai t hitung 9,858 > t tabel 2,034 atau $\mathrm{H}_{0}$ ditolak dan $\mathrm{H}_{1}$ diterima. Artinya, terdapat pengaruh metode bernyanyi terhadap hasil belajar peserta didik kelas III A pada pembelajaran matematika (Perkalian) di MI AlMursyidiyyah.

Lalu, dalam hasil uji hipotesi yang dilakukan pada IBM SPSS Statistics 20 didapat mean (ratarata) dari hasil pretest dan hasil posttest. Dapat dilihat pada tabel berikut:

Tabel 2. Mean Pretest dan Posttest Kelas Eksperimen

\begin{tabular}{rrrrrr}
\hline & & Mean & N & Std. Deviation & \multicolumn{2}{c}{$\begin{array}{c}\text { Std. Error } \\
\text { Mean }\end{array}$} \\
\hline \multirow{2}{*}{ Pair 1 } & Pretest & 63.82 & 34 & 10.449 & 1.792 \\
& Posttest & 88.53 & 34 & 8.214 & 1.409 \\
\hline
\end{tabular}

Berdasarkan tabel diatas, mean pretest yaitu 63,82 dan mean posttest yaitu 88,53. Terdapat selisih pada kedua mean yaitu 24,71. Jika dilihat dari perbedaan antara mean pretest dan mean posttest, maka dapat dikatakan bahwa terdapat peningkatan hasil belajar matematika peserta didik sebelum menggunakan metode bernyanyi dan sesudah mendapatkan metode bernyanyi.

Hal ini dikarenakan syair-syair yang digunakan pada metode bernyanyi disesuaikan dengan perkalian 1-10. Metode bernyanyi yakni pembelajaran yang memanfaatkan soneta yang dinyanyikan. Umumnya soneta disamakan dengan materi yang akan diajarkan oleh guru. (Muhammad, 2012) Video metode bernyanyi yang dibuat peniliti dapat didengar berulang kali, 
Nafia Wafiqni \& Ferdinni Haryanti

sehingga peserta didik dapat menghafal tabel perkalian lebih mudah dan dapat mengerjakan soal perkalian yang diberikan dengan berbekal telah menghafal perkalian.

Adapun unsur yang mempengaruhi hasil belajar peserta didik yaitu wali kelas III A yang memberikan modul setiap seminggu sekali kepada wali murid untuk peserta didik. Lalu, pada wawancara yang dilakukan peneliti oleh wali kelas III A, adanya penggunaan pendekatan sosial, dimana peserta didik yang mengerjakan tugas akan diberi reward. Lalu, adanya videocall secara berkelompok.

Penggunaan metode bernyanyi mampu menambahkan hasil belajar matematika peserta didik di sekolah dasar, hal ini senada melalui hasil penelitian Vera Triatnasari (2017) yang dibuktikan pada siklus yang ke II, peserta didik lebih dinamis dalam sistem pembelajaran karena siswa senang dan bersemangat untuk metode bernyanyi. Pada metode bernyanyi ini, guru dituntut untuk berkreatifitas dalam menciptakan lirik dan menyajikan materi dengan metode ini.

Penggunaan metode bernyanyi menggunakan alat peraga manipulatif mampu meningkatkan pemahaman konsep matematika peserta didik di sekolah dasar, hal ini senada melalui hasil penelitian Suhandani (2018) yang membuktikan adanya peningkatan kreatifitas peserta didik dalam proses pembelajaran. Peningkatan kreatifitas peserta didik terlihat atas hasil penelitian yang dilakukan yaitu tes siklus I nilai rata-rata 75,56. Siklus II nilai rata-rata siswa meningkat menjadi 88,13 . Nilai ketuntasan klasikal juga mengalami peningkatan dari siklus I ke siklus II yaitu dari 60,86\% naik menjadi 95,56\%. Peserta didik dan guru mulai giat ketika pembelajaran berlangsung. Peserta didik juga semakin berani pada saat pembelajaran.

Penggunaan metode bernyanyi dapat meningkatkan hasil belajar IPS peserta didik di sekolah dasar, hal ini senada dengan hasil penelitian Nila Prasiwi (2020) yang dibuktikan pada perbedaan n-gain yang didapat antara kelas yang menggunakan metode bernyanyi dengan kelas yang menggunakan metode konvesional. Hasil penelitian tersebut yaitu pada kelas yang menggunakan metode bernyanyi mendapatkan rata-rata skor 0,71 n-gain. Sedangkan kelas yang menggunakan metode biasa mendapatkan rata-rata skor 0,41 n-gain. Kelas yang menggunakan teknik menyanyi lebih dinamis dalam sistem pembelajarannya karena peserta didik senang dan bersemangat untuk metode menyanyi, berbeda dengan kelas yang menggunakan metode biasa. Pada metode bernyanyi ini, guru dituntut untuk berkreatifitas dalam menciptakan lirik dan menyajikan materi dengan metode ini.

Menurut data diatas, diperoleh kesimpulan yaitu terdapat pengaruh pada hasil belajar matematika peserta didik III A MI Al-Mursyidiyyah setelah menggunakan metode bernyanyi. Dalam pelaksanaan penelitian, peneliti menyadari bahwa terdapat beberapa hal yang belum sempurna. Adapun keterbatasan pada penelitian ini yaitu pada penelitian ini, yang mempengaruhi hasil belajar matematika pada kelas III A di MI Al-Mursyidiyyah bukan hanya dari metode bernyanyi, tetapi ada faktor lain yang mempengaruhi. Faktor yang lain yang mempengaruhi hasil belajar peserta didik yaitu wali kelas III A yang memberikan modul setiap seminggu sekali kepada 
wali murid untuk peserta didik. Lalu, pada wawancara yang dilakukan peneliti oleh wali kelas III A, adanya penggunaan pendekatan sosial, dimana peserta didik yang mengerjakan tugas akan diberi reward. Lalu, adanya videocall secara berkelompok.

\section{SIMPULAN}

Berdasarkan penelitian yang telah dilakukan dan pengolahan data hasil penelitian berupa pretest dan posttest pada kelas eksperimen (kelas III A), diperoleh hasil nilai t hitung 9,858 > t tabel 2,034 atau $\mathrm{H}_{0}$ ditolak dan $\mathrm{H}_{1}$ diterima. Artinya, terdapat pengaruh metode bernyanyi terhadap hasil belajar peserta didik kelas III A pada pembelajaran matematika (Perkalian) di MI AlMursyidiyyah.

Lalu, terdapat selisih pada mean pretest dan mean posttest yaitu 24,71. Dengan mean pretest berjumlah 63,82 dan mean posttest berjumlah 88,53. Bisa dikatakan bahwa ada peningkatan hasil belajar matematika peserta didik sebelum menggunakan teknik menyanyi dan setelah mendapatkan teknik menyanyi.

Sebagai bahan rekomendasi untuk kedepannya, maka dikemukakan saran-saran yang diberikan oleh peneliti, yaitu: 1) Sekolah dapat lebih mempertimbangkan untuk menggunakan metode pembelajaran yang dapat meningkatkan hasil belajar peserta didik; 2) Guru menjadi lebih kreatif dan bervariasi dalam menggunakan metode yang dapat membuat peserta didiknya aktif dan dapat meningkatkan hasil belajar peserta didik khususnya dalam pembelajaran Matematika. Agar dapat menggunakan metode bernyanyi pada semua mata pelajaran, termasuk mata pelajaran matematika; 3) Kondisi yang sedang terjadi menuntut orang tua untuk bisa mengajarkan anaknya dirumah seperti layaknya seorang guru. Orang tua dapat juga mencari metode pembelajaran yang mudah dan dapat digunakan saat belajar dengan anak. Orang tua juga dapat bernyanyi bersama anak, agar anak lebih bersemangat untuk belajar dan hasil belajar anak menjadi lebih baik; 4) Peserta didik diharapkan menjadi lebih rajin, kreatif dan semangat ketika mengikuti pembelajaran Matematika.

\section{DAFTAR PUSTAKA}

An, S., Capraro, M. M., \& Tillman, D. A. (2013). Elementary Teachers Integrate Music Activities into Regular Mathematics Lessons: Effects on Students' Mathematical Abilities. Journal for Learning through the Arts: A Research Journal on Arts Integration in Schools and Communities, 9(1). https://doi.org/10.21977/d99112867

Depdikbud. (1991). Pedoman Guru Bidang Pengembangan Pengetahuan di Taman Kanak-kanak. Jakarta: Proyek Pembinaan Mutu Taman Kanak Kanak.

Depdikbud. (1994). Petunjuk Teknis Proses Belajar Mengajar di Taman Kanak-kanak. Jakarta: Proyek Peningkatan Mutu Taman Kanak-kanak. 
Nafia Wafiqni \& Ferdinni Haryanti

Dimyati, M. (2006). Belajar dan Pembelajaran. Jakarta: Reneka Cipta.

Joewono, B. N. (2013). Guru Matematika Diminta Kreatif. p. 1. Retrieved from https://edukasi.kompas.com/read/2013/03/03/23544181/Guru.Matematika.Diminta. Kreatif..

Mahajan, M., \& Singh, M. K. S. (2017). Importance and Benefits of Learning Outcomes. IOSR Journal of Humanities and Social Science, 22(03), 65-67. https://doi.org/10.9790/08372203056567

Mardapi, D., Hadi, S., \& Retnawati, H. (2015). Menentukan Kriteria Ketuntasan Minimal Berbasis Peserta Didik. Jurnal Penelitian Dan Evaluasi Pendidikan, 19(1), 38-45. https:/ / doi.org/10.1080/14786435.2020.1759835

Muhammad, F. (2012). Desain Pembelajaran PAUD. Yogyakarta: Ar-Ruzz Media.

Negara, H. S. (2014). Konsep Dasar Matematika Untuk PGSD. Bandar Lampung: Aura Publishing. Santoso, S. (2010). Kupas Tuntas Riset Eksperimen dengan Excel 2007 dan Minitab 15. Jakarta: PT Elex Media Komputindo.

Sri Utami, V. (2006). BRAIN POWER Permainan Kreatif untuk Prasekolah. Jakarta: Erlangga For Kids.

Sugiyono. (2015). Metode Penelitian Kombinasi (Mix Methods). Bandung: Alfabeta.

Tarigan, P. B. (2013). Penerapan Metode Bernyanyi Dalam Pembelajaran Mufradat. Journal of Chemical Information and Modeling, 53(9), 1689-1699. https:/ / doi.org/10.1017/CBO9781107415324.004

Trygu. (2020). Studi Literatur Problem Based Learning Untuk Masalah Bagi Siswa Dalam Belajar Matematika. Jawa Timur: Spasi Media Member of Guepedia Group.

Wijaya, H. (2018). Analisis Data Kualitatif Ilmu Pendidikan Teologi. Sulawesi Utara: Sekolah Tinggi Theologi Jaffray.

Yendarman. (2016). Peningkatan Kemampuan Menetapkan KKM Dengan Diskusi Kelompok Kecil Bagi Guru. Jurnal Ilmiah Universitas Batanghari Jambi, 16(3), 122-129.

Yulianto, H. S. (2015). Trik: Mudah Perkalian Dalam Hitungan Detik. Jakarta: Media Pusindo.

Yusmanto. (2018). Peningkatan Hasil Belajar Matematika melalui Metode Bernyanyi di Madrasah Ibtidaiyah. Jurnal Pendidikan: Riset Dan Konseptual, 2(3), 313. https://doi.org/10.28926/riset_konseptual.v2i3.68 